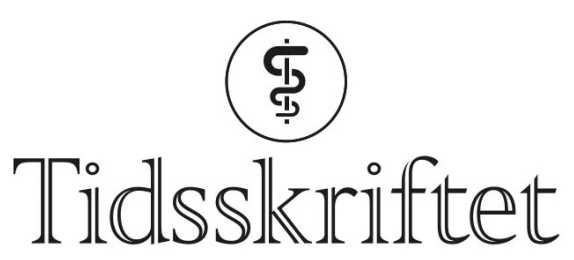

DEN NORSKE LEGEFORENING

\title{
Fascinerende om visuell oppfatning
}

\author{
ANMELDELSER
}

EMILIA KERTY

Oslo universitetssykehus, Rikshospitalet

Nevrologisk avdeling

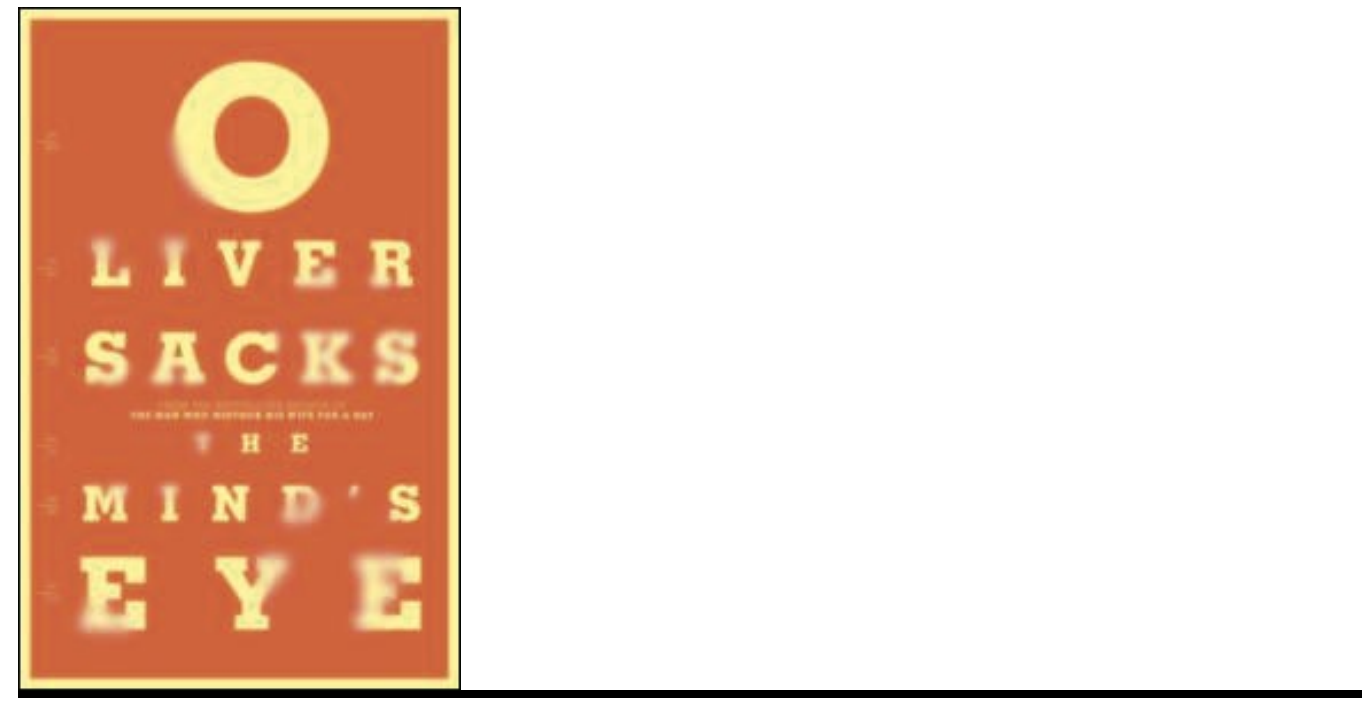

Sacks, Oliver

The mind's eye

260 s. London: Pan Macmillan, 2010. Pris GBP 18

ISBN 978-0-33-050889-6

Oliver Sacks (f. 1933), den kjente, engelskfødte nevrologen og forfatteren, har gitt oss mange glimrende beskrivelser av diverse nevrologiske tilstander. Hans 11. bok er intet unntak. De som likte hans bestselger, Mannen som forvekslet kona med en hatt (1987), vil også ha glede av å lese denne boken som appellerer både til leger og et bredt publikum. Essaysamlingen består av historier hvor personer beskriver sine nevrologiske problemer, de såkalte høyere, kortikale funksjonsfortyrrelsene: synet, den visuelle oppfatningen og gjenkjenningen og hjernens fascinerende evne til å tilpasse seg funksjonsforstyrrelser. 
Første del består av fem sykehistorier. Manglende ansiktsgjenkjenning, prosopagnosia, er en sjelden tilstand og opptrer som regel etter hjerneslag. Vi lærer her at den kan være medfødt og ofte familiær. Den medfødte formen av prosopagnosia er mye hyppigere enn den ervervede, og opptil 2-2,5\% av befolkningen kan ha slike svakheter. Forfatteren innrømmer selv at han har hatt dette problemet i hele sitt liv, noe som har ført til delvis pinlige situasjoner i sosial sammenheng. En annen sykehistorie omtaler en person som mistet evnen til å lese, men som klarte å skrive (alexia uten agraphia). Ironisk nok klarer ikke vedkommende å lese teksten som han nettopp har skrevet.

Sacks beskriver sine pasienter med en slik empati og varme at leseren også føler et nært bekjentskap til dem.

Den andre delen, hvor forfatteren forteller om sin egen sykdom, okulært melanom, er meget personlig. I dagboks form treffer vi pasienten med observasjoner av sine synsforstyrrelser. Og så får han den alvorlige diagnosen. Opplevelsen av den tilsynelatende uendelige ventetiden før behandlingen er enerverende: Diagnosen blir stilt før jul, og behandlingen iverksatt medio januar. Den suksessfulle behandlingen blir brått avbrutt av en intraokulær blødning som fører til synstap på øyet, i tillegg til tap av dybdesyn og innskrenket synsfelt. Gjennom «mind's eye» er han nå nødt til selv å kompensere for de tapte sansene og lære å se stereoskopisk, ved å satse på hjernens plastisitet.

Hvert kapittel avsluttes med forfatterens egne forklaringer og oppdaterte henvisninger til faglitteratur, noe som stimulerer til videre lesning.

Boken er ikke bare underholdende, men gir også nyttig lærdom om sjeldne, men invalidiserende persepsjonsforstyrrelser, som ikke er så lett påvisbare med «vanlige» nevrologiske undersøkelser.

Publisert: 1. juli 2011. Tidsskr Nor Legeforen. DOI: 10.4045/tidsskr.11.0330

(C) Tidsskrift for Den norske legeforening 2023. Lastet ned fra tidsskriftet.no 26. april 2023. 